\title{
Illuminating Existential Meaning: A New Approach in the Study of Retirement
}

\author{
Mattias Bengtsson \\ University of Gothenburg, Sweden
}

\author{
Marita Flisbäck \\ University of Borås, Sweden
}

DOI: http://dx.doi.org/10.18778/1733-8077.17.1.12

\section{Keywords:}

Retirement;

Phenomenological

Approach; Existential

Imperative; Being-

toward-Death;

Second Birth; Social

Inequality

\begin{abstract}
Current discussions on the importance of retirement are largely built on statistical analyses of longitudinal data showing that well-being seldom changes from before to after entering retirement, but is rather mainly dependent on the individual's social resource position. In contrast, qualitatively oriented researchers underline that the retirement process is a complex life transition that needs to be further illuminated. To do this, however, we need to advance new theoretical and methodological perspectives. In this article, an existential sociology approach is outlined, emphasizing the multifaceted spectra of lived experiences and meaning-making in the retirement process. The phenomenological approaches of existential sociology allow us to consider how the exit from working life is created in the processes of motion rather than as expressions of static positions. A merit of this approach is that retirement as an empirical case may say something general about being in transition as a basic social condition. In the article, we discuss how a socio-biographical methodology, based on longitudinal qualitative interviews, helps us capture how existential meaning is formed and re-formed in the ambiguous situations which arise in similar life-course transitions. Theoretically, we especially draw on concepts from the existential anthropologist Jackson and the phenomenological tradition of existential philosophers such as Arendt and Heidegger.
\end{abstract}

Mattias Bengtsson is an Associate Professor of Sociology at the University of Gothenburg, Sweden. His work covers areas such as meaning-making in the retirement process, existential driving forces among older employees, work as a calling, social class and ideological orientations, in-work poverty, transnational union cooperation, and transformations of Swedish welfare state policies.
Marita Flisbäck is an Associate Professor in Sociology at the University of Borås, Sweden. Her research has focused on careers in the arts and culture sector, creative entrepreneurship, questions of recognition, and existential meaning-making in low-status occupations and the retirement process.

email address: marita.flisback@hb.se 
It's obvious that one has more time to reflect when retiring... Retiring is a kind of stopover to a new life... And that, of course, is a reminder that everything's finite. That's the way it is... It's, therefore, unavoidable. That's how it is!... On the one hand, it's the phase in itself; on the other, as long as you're working, you don't have the time to think about anything

else... The more one works, the more involved one is, the less time one has for those second thoughts on what there is; but, as a pensioner, one has more time to do this. [George, former dustman aged 67 years, after the point of retirement]

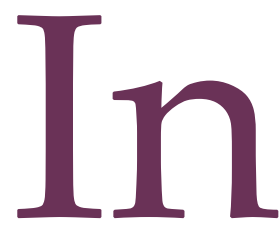

retirement research, existential meaning-making in the lived experiences of individuals, such as that expressed by the former dustman in the quote above, is often downplayed. Economic and demographic questions are instead at the center, such as how people in Western societies will be required to work longer (e.g., Reynolds, Farrow, and Blank 2012; cf. Biggs 2014; 2015). In Sweden, where we have conducted our research, the latter question is high on the agenda in politics, in the media, and among researchers. In late 2017, representatives from six political parties in the Swedish Parliament presented a political agreement to raise stepwise the lower retirement limit from 61 to 64 years of age and the upper limit from 67 to 69 years of age. ${ }^{1}$ According to Norbert Elias and John

\footnotetext{
${ }^{1}$ Sweden, which has a system of mandatory retirement, previously had a fixed retirement age of 65 , but a more flexible system was implemented in the new century. At the time of writing, the minimum retirement age is 62 and the maximum is 68; that is, at a 68 -year limit, the employee will have to let go of his/her status as permanently employed, but has the opportunity to seek fixed-term employment in the labor market.
}

Scotson (1994), a researcher can easily respond instrumentally to similar politics by offering advice on the most efficient execution or, contrariwise, pointing to negative implications of these policies. Either way, other approaches to retirement than those on the political agenda can thus be made invisible, such as existential issues that are awakened in the transition between exiting occupational life and having a new everyday life as a pensioner. Existential issues, though, are essential for a deeper knowledge of how the individual handles welfare policy changes in the direction towards increased responsibility for their provision, for health, and life possibilities within the frame of a general human wish that one's life should be of importance in a wider existential context.

Retirement research often uses statistical analysis techniques to study antecedents and outcomes (such as health, well-being, and economic and psychological adjustment) of the transition and the post-retirement trajectory (Van Solinge and Henkens 2008; Muratore and Earl 2015). Data show that well-being and health seldom change after-compared to before-the entry into retirement, but instead mainly depend on the individual's social resource position from earlier life (Hyde et al. 2004; Halleröd, Örestig, and Stattin 2013). From this perspective, the social phenomenon of retiring is considered to have only a minor effect on the lives of human beings. However, we assert that qualitative methodologies and analyses are needed to capture intersubjective meanings of retirement that are not quantitatively measurable, but are still so noticeable when an individual leaves a well-known, habitual everyday for the new everyday of retirement.

Consequently, the aim of this article is to illuminate the issue of retirement from a qualitative method- 
ological perspective and underline the existential meaning of the transition from an employee to a pensioner. Highlighting questions as existential means focusing on how the significance of life is always part of our choices, concerns, worries, and well-being. Existential questions could concern both ethical and social problems, as well as how we as social human beings handle the questions of life and death (Jackson 2005; 2011). In relation to retirement, existential reflections could especially involve choices and paths taken during a long occupational life, and the hopes and fears of what the future has to offer.

In this article, we primarily use theoretical arguments, emphasizing how the retirement process makes existential issues particularly noticeable. However, we also occasionally use empirical illustrations to clarify and concretize the existential issues pointed out. The presented existential approach was developed in a research project whose main data consist of interviews with 43 individuals in various professions, 35 of whom were interviewed in two rounds, both shortly before and after the point of retirement. ${ }^{2}$

The analyses of the interview data have shown that retirement can be regarded as a life situation in which questions about meaning, values, and belonging are particularly defined, as well as redefined, according to how one perceives the past and the future. As George expresses in the quote above, the process of retirement can be a reminder

\footnotetext{
${ }^{2}$ The research has been enabled by research funding from the Kamprad Family Foundation for Entrepreneurship, Research \& Charity (the project "Towards a New Everyday: Individuals' Meaning-Making at the Entry of Retirement from a Social Inequality Perspective," grant no. 2013-0049). The authors would like to thank Anna Lund for her comments during the research process.
}

of life's finitude as a universal existential condition that is played out in singular life events (cf. Denizeau 2015).

We will argue that illuminating retirement from a qualitative methodological perspective can be fruitful when highlighting the existential meaning of the process. In relation to this, we point out some theoretical concepts when interpreting retirement from this approach. As the reader will see, we emphasize the multifaceted spectra of lived experiences and meaning in the retirement process and its "uncertain possibilities" (Jackson 2013:162). We capture these uncertainties/risks and possibilities with the concept existential imperative, which is taken from the existential anthropologist Michael D. Jackson. In addition, we have found the phenomenological perspectives of existential philosophers Hannah Arendt and Martin Heidegger fruitful. We especially draw on the idea of how human beings particularly become aware of their mortality in life situations when something is broken, missing, or left behind. However, in these situations, it can also become apparent that human beings have the possibility to start over and choose new life paths.

When we set forth a research agenda here to study how individuals manage uncertainty in life-course events, such as the retirement process, and present some essential theoretical concepts to be used as tools for capturing the existential and qualitative meaning of this, we will mainly discuss its significance from a sociological perspective. In the final part of the article, however, when we draw some main conclusions, we will also elaborate on how similar existential questions may be of importance in the contemporary political and social contexts mentioned above. 


\section{A Methodology for Illuminating Existential Meaning}

The main assumption in our approach is that of a multifaceted retirement process, encompassing a variety of experiences that can be understood in their complexity by highlighting the concept of existence (cf. Denizeau 2015). Highlighting existential issues is important when considering retirement. For many people, retirement is a life phase in which one's work identity fades away. Additionally, one's private-role identity can be threatened, such as when "[c]hildren have their own lives; partners pass away" (De Lange 2011:51). Studies show how existence as a pensioner fosters attitudes about not only the value of work, but also one's usefulness or self-realization. With the aging process, existential questions of the unpredictability and vulnerability of life may also be emphasized (Tornstam 2005; Holm 2012; Osborne 2012; Biggs 2014).

Even if statistical analyses have shown a declined impact of retirement on our lives, qualitative researchers still underline that regardless of when, and in what way, people retire, the process is an important life transition. From this perspective, there is a call for approaches studying the "complex, unfolding process" of retirement (Jonsson, Josephsson, and Kielhofner 2000:464) and illuminating experiences of retirement as "situated within individual histories and cultural contexts" (Luborsky 1994:411). In order to take on this challenge, however, we need a methodology, as well as perspectives and concepts that are helpful in framing such qualitative analysis. As sociologists, we have previously highlighted existential questions where life both ends and continues; for example, when one becomes a parent, enters the labor market, or loses a loved one (see, e.g., Flisbäck 2014a). In this research project, we continue to investigate similar existential themes by focusing on individuals' meaning-making in the retirement process in a welfare society such as Sweden.

As the aim of this article is to contribute to methodological and theoretical approaches that can enable studies of the existential meaning of retiring, the empirical material analyzed within our research project is used only as examples and illustrations (for more detailed information about our empirical analyses, see: Bengtsson and Flisbäck 2017; Bengtsson, Flisbäck, and Lund 2017).

To say a few words about the empirical material: all interviewees had been employed and had retired in 2014 or 2015. In order to obtain a variety of professions, sectors, and activities, we focused on five groups: low-skilled, manual jobs; skilled jobs in the public sector; occupations dealing with abstract means; high-skilled professions mainly dealing with existential questions; and occupations within the creative industries.

A starting point for our research project is that retirement is a phase in which previous years are evaluated, at the same time that the coming years as "elderly" are considered in relation to existential questions (see, e.g., Holm 2012; Osborne 2012; Biggs 2014). To gain an understanding of how meaning can shift over time in this phase, the same individuals were interviewed both a shorter time before the point of retirement and approximately half a year afterward. A so-called socio-biographical methodology was used, meaning that social structures were analyzed through individuals' narratives (cf. Flisbäck 2014b).

The socio-biographical method has similarities to both life-history interviews and the life-course ap- 
proach, the latter of which has been rather dominant in aging and development studies (cf. Alwin 2012). An advantage of all these methods is the analysis of trajectories by emphasizing both contextual factors and intrapersonal development (e.g., Elder, Kirkpatrick Johnson, and Crosnoe 2003). However, the socio-biographical method differs in its stronger focus on shifting meaning and existential themes (Flisbäck 2014a; 2014b). One benefit of the method is that it permits us to see how "internal" differences in each interviewee are displayed over time-in transition between different social milieus. In other words, the method makes visible how similarities and differences emerge both within and between groups, but also how meaning changes within each subject over time (cf. Braidotti 2011).

An increased interest in longitudinal studies within qualitative research has been described as "part of a 'temporal turn' within the social sciences" in general (Thomson and McLeod 2015:244). From this perspective, the method has several advantages. One is the ability to capture processes over time. Another is the possibility to follow individual life trajectories and to see how culture and meaning in social groups develop. In addition, the method can contribute to new interpretations of what social scientists regard as progress and decline in social life (Thomson and McLeod 2015).

While longitudinal qualitative interviews shed light on how cultural and existential meaning is formed over time, there are some inherent difficulties, for example, the opportunity to arrange a follow-up interview. The interviewees may be less interested if they have experienced difficulties in life and believe that life has not developed as they had hoped (Miller 2015). However, an eager existential sociologist needs to shape a climate such that it will make follow-up interviews possible, even in difficult times. It is important that both joy and sorrow, chance and risk, initiative richness and defeatism are included in an analysis aimed at understanding how people deal with "existence" and the important breaking points of life. In relation to this, our interviewees have often been eager to talk about the ambiguities and setbacks in their lives. As emphasized by psychologist Erik H. Erikson, aging may bring forth a longing to summarize one's life (Erikson, Erikson, and Kivnic 1986). In other words, telling one's personal life story and sharing the enigmas of life may have an existential reconciling effect.

Follow-up interviews, such as the socio-biographical method, are important when studying the details of individuals' existential dilemmas and life paths, but in a way that visualizes the links between the singular and the shared historical and social contexts. Similarly, Arendt described the importance of good examples, whereby the lives of individuals are transferred into universal cases. In her biographical study of Rahel Varnhagen, Arendt (1997) shows the value of detailed analyses of individual lives in their transferability in relation to her contemporary readers. And, as we will see, in a similar way, focusing on the lived experiences in a life-course event such as the retirement process can add something important with regard to what it means to be a human being.

\section{A Phenomenological Approach}

The methodology described above is found in Flisbäck's (2014a) study of a group of female artists recurrently interviewed during a 14-year period, examining existential issues through the relation between work, loss, and family formation. The 
study not only highlights the relation between work and parenting-common in studies of family life-but also includes the loss of relatives. Although the sociology of family life previously treated family, work, and time from a generation- and resource-based perspective, the parallelism of life's origin and finitude has rarely been illuminated.

The study on artistic careers and family life, as well as our study on the retirement process, are both built on the assumption that life and meaning-making are multidimensional. Therefore, we need to focus on how meaning-making in different social processes and social spheres is inter-connected (cf. Douglas 2010; Jackson 2013). This means that we are less interested in analyzing cross-sections of the social world-distributions or patterns at a given time-than in highlighting shifts in meaning-making over time. In line with this, our approach contains a phenomenological point of view that is open to the whole spectrum of meaning and, thus, does not a priori exclude any potential relation or aspect (Arendt 1978).

The aim of phenomenology is to understand human existence from the place or situation where human beings experience and face the world. It can be understood as a way to study the-often implicit-meaning that exists in our relationship to the world, and to explore the meaning horizon appearing at the sight of different objects (Heidegger 2008). To give an example, people in Sweden annually receive an orange-colored envelope by regular mail from the Swedish Pensions Agency. This envelope contains forecast information on a person's financial situation as retired, based on their accumulated taxed income to date. From a phenomenological perspective, the sight of this envelope refers to a whole context of meaning, such as concerns and beliefs about economic (in)security and managing financial risks, the approach of old age, the individual's responsibility for making plans for their future, et cetera.

The example above tells us something important about how the meaning of existence is experienced when handling shared objects, common tools, and language in everyday life (cf. Heidegger 2008). From a phenomenological point of view, this means that the subject's perceptions of things are never separated from the world. Arendt (1978:19, emphasis added) calls this "the worldliness of living things." This tends to be obscured in modern societies, often emphasizing the subject as autonomous and concealing the world as something shared.

From Arendt's (1977) point of view, in studies of history and society, there is a risk of overlooking the ambiguity and diversity of human lives. Many researchers are tempted to make abstract models and forget the uniqueness of human beings' lived experiences. Accordingly, for Arendt, the unpredictability of social life and individuals' life paths is the only thing that we, for certain, can say is typical of humans. Our interviews, both before and after retirement, show that there is great variation concerning orientations towards retirement. While some embrace the opportunities they have been given, others ask what the point is in finishing a life project that has solely concerned the sphere of work. In the latter case, the image of oneself as a future pensioner can be reluctantly formed. But, it is important to stress that one of the points of our phenomenological and existential methodology is to determine how existential meaning is formed and re-formed, and how individuals find new paths in the break with old routines and the meeting with new experiences. 
In applying a phenomenological point of view, we diverge from some perspectives in aging and retirement research whereby human beings are conceptualized as rational, calculative decision-makers (cf. Wang and Shultz 2010). To object to such a view of human beings as weighing the costs and benefits of alternative choices to reach their goals is common in sociological research. It is less common, though, for sociological analyses of retirement to focus on how meaning is continuously formed and shifting in time and space. But, there are interesting exceptions to this, such as in a phenomenological study of reasons for having taken early retirement, in which Robertson (2000:66) emphasizes the "multiple and overlapping ways" the interviewees talk about their reasons for early retirement-in this way, the reasons are "fraught with shades of ambiguity." Both Robertson's study and ours indicate that the retirement process can be seen as a critical case for understanding the maintenance and shifting forms of existential meaning always inherent in life's transitions.

By applying a phenomenological approach, we try to offer an approach to the study of retirement by uncovering existential issues that are more or less absent. This also requires attempts to transcend theoretical boundaries, similar to how Lars Tornstam (2005:29-30) describes the theory of gerotranscendence in the field of aging as an endeavor to "break free from the traditional, sometimes mythical gerontological presumptions" (of positivist and behaviorist origin) in order to seek "a fuller description and understanding of behavior and consciousness by elaborating the meaning that it has for the individual." However, while Tornstam's objective is to present a developmental theory of positive aging, we illuminate retirement as an external event that acts upon people, conceptualized as what Jackson has framed as an existential imperative.

\section{Retirement as an Existential Imperative}

Hitherto, we have emphasized the need to illuminate meaning-making in the retirement process in terms of an individual existential quest. As seen in a review of two decades of retirement research (Wang and Shultz 2010), studies have usually dealt with issues such as early retirement, retirement planning, retirement decision-making, bridge employment, retirement adjustment, and post-retirement health and activities. As stressed above, our objective is instead to illuminate the "shape-shifting" of meaning throughout the retirement process. A similar idea is found in a study by Jonsson, Josephsson, and Kielhofner (2001), which shows how the meaning of activities can shift when the former clear boundaries between work and leisure time have dissolved in the transition from employment to retirement. Jonsson and colleagues (2001:428) describe the shifting meaning one interviewee ascribes to going to his summer cottage after retirement:

\footnotetext{
Before retirement, going there allowed him to escape the demands of the workweek and to rest and relax; it was a well-earned retreat before the next period of work. But once he no longer worked, going to the cottage did not feel the same. The joy of relaxing and well-earned rest was, to his surprise, no longer present. It no longer had a relationship to another part of his life.
}

The participants in the study by Jonsson and colleagues depict the transition from work to retirement as being more complex than they had expected. The main reason for this is that both the job and leisure activities took on new meaning when they became part of a new pattern of life in the process of exploring a new everyday. In other words, the 
meaning of the practices changed when the relationship between the different life spheres shifted over time.

Traditionally, when the shift of meaning in people's lives in relation to retirement has been explored, it has been described as a "rite of passage" (cf. Atchley 1976). A main theoretical contribution by the anthropologist Arnold van Gennep is his conceptualization of life in terms of various passages in which it changes form and condition (e.g., birth, social puberty, marriage, and death). Van Gennep's (1960) examination of life-course events, and their accompanying ceremonies, led him to develop a threefold classification of rites of passage as activities symbolizing separation, transition, and incorporation. The transitional phase, consisting of so-called "liminal rites," is of specific interest here in our theoretical elaboration on the retirement process.

The anthropologist Victor Turner (1974:232) describes the second, transitional phase in terms of the "liminal period," whereby the person "becomes ambiguous, neither here nor there, betwixt and between all fixed points of classification; he passes through a symbolic domain that has few or none of the attributes of his past or coming state." Liminality, thus, refers to a state that is set apart from social structure and its accompanying statuses and roles. We could call it in-between social structures. In other words, people are situated in an interval between fixed structural positions, so that when they move into the third phase, they re-enter the social structure in which "the units are statuses and roles, not concrete human individuals" (Turner 1974:237).

However, to better understand the "workings" of the retirement process, lived reality must not be reduced a priori to a system of roles and symbolic representations (cf. Denizeau 2015). Thus, we should more seriously take into consideration the meaning-making activities of human individuals of flesh and blood. Even if Turner's notion of liminality offers an important view on circumstances in which people may reconsider and contest socio-cultural values and make symbolic orders visible, transitions imply more than this. With the concept of existential imperative, Jackson (2015:174) launches a perspectival shift: there exists, according to Jackson, "an ontologically 'primitive' imperative to act in some way or the other in response to the actions of others or the world at large-to be a who rather than merely a what." As life is more than bare survival, people are in a constant struggle for being against forces beyond their control in order "to possess a sense of themselves as actors and initiators" (Jackson 2013:14; see also Jackson 2016). Inherent in all transitions, according to Jackson (2011:xi), is the promise or hope of something else, a "sense that one may become other or more than one presently is or was fated to be." But, that which offers hope and a new beginning could just as well turn into anxiety and discontent if one's hopes are dashed or one does not believe one's dreams can be realistically fulfilled.

This double-sided nature of life transitions may become more pronounced in more directly life-threatening situations, such as natural disasters, war, or poverty. When we argue here that this is also the case in the retirement process, the point of emphasis is separation-the person is retiring from employment, but what they are retiring to is more uncertain (cf. Atchley 1976). This unpredictability can bring forth individualistic strategies for managing everyday life, following Thompson (1993:685, emphasis in original), as the everyday of 
retired people is no longer structured by common activities like work or regular education, which means "they must choose; responsibility for structuring their lives is uniquely their own." Thus, the retirement process can be seen as decoupling from a collective context and, like other individualization processes, can be interpreted as a life transition whereby questions of meaning and quality of life become particularly prominent (cf. Frankl 1988; Giddens 1991). That is, as individuals are acted on by powerful external forces-for instance, in Sweden, the mandatory institution of retirement-they may experience a loss of control, but a belief may also arise that it is possible to arrange their life beyond the given directives, customs, habits, and regularities. Accordingly, existential imperatives include the potential for change and the redefinition of former meanings, values, and beliefs. However, a main empirical question is whether or not new possibilities will be initiated by the pensioners in their struggle for a viable existence, depending on whether they feel life is worth living or are strained by feelings of meaninglessness or a lack of resources (cf. Jackson 2005; 2011).

\section{Existence within Limits and the (Possibility to Mark the) Right to One's Own Life}

Existential imperatives should be seen as life situations when existential questions tend to be awakened or reinforced as the limitation in time and space becomes apparent to the individual. In his fieldwork performed in Sierra Leone, Jackson has often analyzed existential imperatives in the light of losses resulting from civil war and starvation. But, other types of life situations can also lead to existential imperatives, such as when we exit occupational life and put this everyday behind us to retire. One aspect that can be palpable in the retirement pro- cess, understood as an existential imperative, is the negative effects of wage labor. When another everyday is possible, the experience of being subordinated and exposed in working life can be reinforced. This is the case with the dustman called Olle, who in strong words expresses his relief at being a pensioner, where the best thing about this new everyday is being released from the early rising that was part of his job:

this with the alarm clock in the morning, that one could feel sick about towards the end.

In the existential imperative's experience of the possibility to leave the disciplinary nature of wage labor, retirement may become an opportunity in life when the driving force is even stronger to mark the right to one's own life. This is the case for Jan, who also worked in the recycling industry, but at a recycling station. For several years, Jan felt dissatisfied with work, which was related to changing working conditions. But, he did not express this dissatisfaction before the retirement process. At an informal farewell ceremony in his final working week at the recycling station, he took the opportunity to express his dissatisfaction. When asked by his manager to work temporarily in his new everyday as a pensioner, Jan manifested that he did not want to set his foot in that workplace again:

"Jan," he said. "I ask you, can you imagine working after you've stopped working here?" he said to me. "No," I said, "I can't imagine doing that," because I was a bit bitter then.

Being situated in vulnerable and marginalized positions has been described, by Jackson (2005), as a tangible experience of being drained of life energy, lacking the effort to change one's situation. The vul- 
nerability is related not least to lack of resources. As emphasized by Jackson (2015:170, emphasis in original), a scarcity of material goods translates (in existential terms) "into a sense of being socially without." However, in similar situations, human beings rarely accept their current circumstances, but rather hope and dream for a better future. They sometimes even place their hopes in a magical or divine intervention (Jackson 2011; 2013).

Within the frame of an existential imperative, the individual can gain the power to try to recapture the right to their life that they believe they have, as in the case of Jan. Sometimes the build-up of power can even be experienced as a final attempt, driven by this universal human longing to be an actor in one's life circumstances (Jackson 2005). In Jackson's line of reasoning, while the yearning for something else is a universal human characteristic, the realistic possibility for a changed life situation is circumscribed by social conditions associated with different forms of capital. Human beings, in Jackson's (2011) terms, always live their "life within limits." Like Jan, we can object to a particular situation, but this is not the same thing as having the power to change it-even if the existential will to "improve" our conditions is something we all experience.

The experience of material scarcity and its effects on meaning-making seem to be prominent in the retirement process. George, the former dustman quoted in the introduction, describes-in contrast to the other interviewed workers in the recycling industry-the retirement process as less meaningful. Even though he has a large family, he regards work in general as the most important practice in life. From his perspective, work is a way of shaping an image of yourself as a human being, since as a worker you are useful to your fellow man. However, the only potential source of meaning in the new everyday George was able to see before he retired was to travel to a warmer country in southern Europe. Below, before retirement, he expresses a longing to "leave the cold and the slush" in Sweden. His desire can be understood as a will to leave some of the things that he, after all, saw as negative in his old way of living-for instance, the experience as a dustman of having snow- or rainsoaked shoes:

Gran Canaria is amazing...That's something I do like... Yes, I do like that... The first half-year as a pensioner, then it'll be winter... Then the plan is to travel [with his wife] down to the Canary Islands.

Four months after retiring, when George describes his new everyday, it is relatively meaningless. Now, he cannot serve any real function in society, and the only source of meaning that he saw before retirement-traveling to the south of Europe-does not seem to be economically feasible:

We [George and his wife] like that, going traveling, and such things, but it's true that even that's affected. It's not just a matter of simply traveling, anyhow, because it's expensive.

George longs to visit warm places, but is unable to do this due to his finances. This can be interpreted as a metaphor for the discrepancy between what we are and what we wish to be, that is, the existential mood that Jackson (2011) asserts distinguishes all human beings. In other words, George's case illustrates "the mystery of existential discontent-the question of why human beings...are haunted by a sense of insufficiency and loss" (Jackson 2011:xi). The example underlines that a sociological perspec- 
tive, illuminating the existential meaning of the retirement process, must focus on how individuals' struggle for being is related to social contexts of difference and inequality (cf. Thompson 1993).

\section{An End and a New Beginning}

Longing for a new situation and the possibility to mark the right to one's own life after having been in the hands of others is, thus, a possible effect of retirement as an existential imperative. But, to understand why the specific driving force is accentuated in the retirement process, we need additional concepts that can capture the existential mood that can be brought forth. In other words, the concept of the existential imperative is important for comprehending existential dilemmas that may be at stake in the retirement process; but how can we gain a deeper understanding of why the willingness to speak up, as in Jan's case, can be strong in relation to the point of retirement?

In our analyses, it has become evident that the retirement process is an essential breaking point in life that can reinforce an individual's thoughts that they have a limited number of years left to live (cf. Marshall 1986; Holm 2012). For example, Jan's wife, Ann-Marie (a former preschool teacher, who was also interviewed in the project), stresses that in the retirement process, life's limitation in time and space has become apparent. As she sees it, this experience is less positive. When friends and family sometimes express jealousy, since Ann-Marie as a pensioner has "escaped work", they do not understand that for her the process also has meant a loss of youth and looking back at things past. In the interview, she explains that both she and her husband, at the point of retirement, were so strongly reminded of this:
Well, now we have all these years behind us, and only a few years ahead of us!

When Ann-Marie describes her insights, she compares retirement to crossing a border:

Now it feels like one has one foot on the other side.

To capture and illuminate similar existential experiences, we have leaned towards the phenomenological ambition to find new aspects of meaning-making in everyday life, when the unfamiliar is sought in the familiar. In Heidegger's terms, we can talk about a feeling of being-toward-death (Sein-zum-Tode) being accentuated. The "reminder that everything's finite," as George expressed in the first quote of this article, has produced an understanding that man is not the "master" of his life. According to Elias (1985), such insights are often neglected in modern Western capitalist societies as finitude is turned into an abstract, statistical probability, and death is seen as an abnormal diagnosis unrelated to everyday life. In relation to our example, this means that experiences of the retirement process may entail that death-as a lived existential condition-are often made into experiences of "they" (Das Man), to speak in Heidegger's (2008) terms. Most likely, this is why some aging studies have called for approaches whereby life and health issues are studied in relation to existential meaning-making and spirituality (Kimble 2002; Tornstam 2005; Dalby 2006; Biggs 2014).

Making space for existential issues in the retirement process is not only due to a more tangible situation of being-toward-death. It also occurs when one has more time to reflect on one's existence, as described by a doctor called Jens in our study. In the final year before he planned to take out his entire pension, he has gained time to reflect on his life by taking out 
a part-time pension. He thus has more free time to philosophize over the retirement process:

to philosophize over what it means to be a pensioner, and to make a transition.

At the same time, according to Jens, the farewell to work is experienced as "a divorce" or even "dying" because it is so "definite." For Jens, the transition seems to have created an existential mood.

To sum up, in the event of saying farewell to work a feeling of being-toward-death may arise, and the process may also give space for reflection and make visible different meaning contexts of which the individual is a part. Following Heidegger (2008), a wider meaning context may be revealed in the cleft between familiar places. From Jackson (2005), we have learned that this cleft may be a breaking point-an existential imperative-that gives rise to resistance and the formation of new existential meaning. However, if it is hard to find existential meaning in the new situation as a pensioner (as in the case of George), this may also lead to existential frustration (Bengtsson and Flisbäck 2017; cf. Frankl 1988). In other words, allowing space for something new is always intertwined with giving up something else, such as meaning-making in, and through, work. Therefore, we need to conceptualize lived experiences in the retirement process as containing both loss and (re)birth, endings (such as exiting employment and its specific conditions), and new beginnings (such as starting a new everyday as a pensioner).

As noted, we are inspired by Heideggerian thoughts, such as the idea of existence (Dasein) as something unfixed and, thus, containing unpredictability and opportunities. For a sociologist, this idea might be more comprehensible in Arendt's historical and po- litical studies, since the analyses are done in relation to concrete cases. ${ }^{3}$ Following Arendt (1998), the unpredictability of human actions is persistent in our always fragile life contexts. The Arendtian assumption that the most characteristic aspect of human existence are openness and uncertainty challenges the common idea in the social sciences-not least sociology - that human actions ought to be explained in terms of institutional regularities or cultural and structural representations.

Neither Arendt nor we deny that social life consists of regularities; but we do emphasize that individuals, throughout life's unpredictable twists and turns, may start anew and see the world differently. Life may take other directions, which Arendt (1998) calls a second birth (cf. Erikson 1972). Or, following Vasterling (2007:89), Arendt strives for "understanding real life" as being "without closure." For the sociologist studying the end of occupational life and the beginning of retirement, this is, of course, an exciting thought.

\section{Towards an Existential Sociology of Retirement}

Alongside theoretical inspiration from Jackson, Arendt, and Heidegger, our approach joins existential sociology. This sociology approach originated in the US in the 1970s, where some sociologists criticized mainstream sociology for excluding the ambiguous aspects of everyday life in favor of an "objectified or absolutistic view of man and society" (Manning 1973:200). Inspired by existential psychology and philosophical and literary existentialism, existential

\footnotetext{
3 Vasterling (2007:85) points out Arendt's influences from Heidegger, but underlines differences concerning form and production: "It is the commitment to understanding phenomena and their underlying experiences, rather than concepts, which defines Arendt's phenomenological attitude."
} 
sociology was elaborated to illuminate the richness of human experience and issues of the ambiguity and vulnerability of life. ${ }^{4}$

The existential sociologist Jack D. Douglas (2010) argues that the existential sociology perspective not only understands how individuals solve ambivalence, but also examines experiences of meaninglessness and incomprehensibility. The researcher should be open to the entirety of situations and experiences people find urgent in their lives: "Nothing about man in society is irrelevant to our study; nothing about what is truly important in his life is prejudged or predefined" (Douglas 2010:4). Adopting an existential sociology approach in the study of retirement, therefore, is to embrace an alternative point of view: shifting attention from regularities towards transitions and ambiguities as the basis of life itself.

An important assumption in existential sociology is that specialization (in social fields such as work, family, etc.) is not the main road to follow, but that the researcher should instead try to analyze links between phenomena in various social fields in order to seek the entirety of aspects people may find meaningful (Flisbäck 2014a). Existential sociologists are mainly interested in issues related to fundamental life choices, passions, commitment, and perceptions of bodily changes, and death. Often, they tend

\footnotetext{
${ }^{4}$ The existentialist viewpoint includes a diversity of perspectives, as well as writers and philosophers who do not accept the term in itself (Kaufmann 1969). If, nevertheless, an attempt is made to summarize some existentialist starting points, a common interest involves approaches to life and death, fear and anxiety, perceptions of coercion, and the issue of man's freedom of action. What is also characteristic of the "spirit of existentialism" is that all human beings are seen as "concrete individuals of blood-and-bones creating their ways through a world in which meanings are highly problematic and situated" (Fontana 1980:155-156). Thus, common to many existentialists is a phenomenological point of view (Kaufmann 1969).
}

to examine how unpredictable actions arise out of people's longing for love, trust, dignity, recognition, and respect, or from their attempts to free themselves of power relationships (Kotarba and Johnson 2002; Douglas 2010).

A central idea of existential sociology, in other words, is that we need to put together all these various existential experiences of the social world and try to understand it in a broader context and over time. A similar approach is found in existential anthropology. In an introductory chapter on this approach, Jackson and Piette (2015:3) criticize the fact that the multifaceted, complex, mutable, and vibrant nature of life tends to be forgotten in the social sciences in general when lived reality is reduced a priori "to culturally or socially constructed representations." By contrast, both existential anthropology and existential sociology emphasize the need for theory and methodology that are able to capture the concrete varieties of meaning in the fragile lives of human beings.

Thus, both research traditions call attention to the notion that "the existential" content of lived reality-the fundamental "precariousness of presence" (Jackson 2005:xiv) or vulnerability of the human condition-tends to be reduced to something else. For example, sociologists have often conceptualized religion and religious experiences as social practices or ideational systems that give rise to emotional or cultural forces experienced as something greater than the individual self (see, e.g., Durkheim 1995; Alexander and Smith 2003; Collins 2004). However, following Jackson and Piette (2015), being a socially situated human being has an extended meaning beyond maintaining social practices or ideational systems. Inspired by the religion psychologist William James, Jackson and Piette state that God may be seen as an idea to which the self turns in order 
to transcend oneself. This can be understood as an existential driving force that makes life about more than simply the here and now. Thus, religious life can be analyzed not only as an external social force or as a metaphoric, cultural dividing line between the sacred and the profane. "The will to believe" (James 1912) can be interpreted as an expression of the existential struggle we have seen springing from the individual's hopes and fears about life taking new directions.

A similar transcendent quest may arise in the lived experiences of the retirement process, whereby the self harbors doubts with regard to future possibilities, but simultaneously longs for another existence. Let us finally illustrate this with an example from one of our interviewees, called Anna-Britta, a librarian working with information and books for younger children. Her story exemplifies how existential meaning can be (re-)formed in the retirement process.

We have interpreted Anna-Britta's retrospective account of occupational life as an orientation to work as a calling (cf. Bengtsson and Flisbäck 2017; 2020). To serve a higher cause-one's fellow man or the community-one of her most important duties has been to increase literature reading among resource-poor children. Moreover, her desire to make a difference was seen in the impact her committed work had on the parents of these children:

I've made them go to the libraries. Many of the parents had never visited the library before.

However, experiences of a constant shortage of time and increased administration work in her job over time have made Anna-Britta see the benefits of leaving work:
There's so much putting books back on the shelves and so much administration to handle. And that's something that's pretty hard. So that part of the job, I won't miss it [as a pensioner].

According to Anna-Britta, these burdens compete with the duties she regards as truly important, such as meeting the children and their parents and introducing them to the world of literature and fairy tales. In relation to presenting books to school classes, she says:

You know, all the energy you get from talking to the kids, I can't describe it!

The quotes above exemplify how Anna-Britta, through a passionate commitment to a cause, in Max Weber's terms, has lived for her work, that is, made work her life "in an inward (innerlich) sense" (Weber 1994:318, emphasis in original). Her work orientation illustrates the importance-for a sociologist-of not excluding the existential and religious aspects of life, here metaphorically understanding work and life as a struggle to find and listen to callings. This is of significance not least since understanding work as a calling also leads us to see something about the contradiction that people can feel trapped in concerning the demands of their current working life. For Anna-Britta, the increased burden of tasks such as administration becomes an obstacle to achieving the higher cause of making a difference for others. Thus, she has started longing for another existence, to be something otheror even more-than she experiences is possible in her current occupational practice. In other words, in the potentially "second birth" of retirement, Anna-Britta has begun listening for another form of calling-not least from the private sphere.

Before the point of retirement, Anna-Britta hopes she can engage more fully in her grandchildren, but 
also hopes to have more time to reflect and to translate her creative potentials, such as writing stories of her own. This is something she has felt has been lacking in her former life. In this way, the lived experience of the retirement process has resulted in what we can describe as a form of existential reconciliation that makes it reasonable for her to leave a former calling and emphasize future possibilities in a new phase of life. But, this is not always the case, as Douglas underlines in his existential sociology perspective: often, existence only offers enigmas and not settlements. However, Anna-Britta's example shows the importance of not ruling out the existential implications of the social institutions of modern life, such as retirement.

\section{Conclusions}

The aim of this article has been to outline a qualitative existential approach in the study of retirement, emphasizing the multifaceted spectra of lived experiences by studying retirement as a process whereby meaning is continuously formed and re-formed. This transition may create a state of ambiguity that can be experienced and managed as both a risk and a possibility. To capture this, we have emphasized the importance of phenomenological interpretations of the world as a shared meaning context, though always (re)interpreted and experienced in a unique way from the place where one is situated. The phenomenological approach allows us to consider how social life is created in the processes of motion rather than as expressions of static positions. In line with this, it is necessary to employ a qualitative method that follows the transition of the individual through time. In the research project, we used a socio-biographical method, a qualitative longitudinal method specifically focusing on how existential meaning is created and re-created over time, before and after retirement.
An issue in previous research is whether retirement should be seen as a decisive change in the individual's life, or if past life patterns are more decisive for how the process takes shape. We suggest an approach that asks the question differently since neither the assumption that nothing happens nor the one that the retirement process is a main shift take into consideration that life and existential meaning are continuously being formed. However, focusing on forms of meaning-making in the retirement process can be particularly interesting because individuals are leaving the shared meaning context of work. What the future may bring is now more open than previously, at the same time as the new everyday can offer more time to reflect upon the years that have been left behind. With the concept of existential imperative, derived from Jackson, we have tried to capture displacements in meaning that the retirement process can create. We have even pointed to how retirement as an existential imperative can offer possibilities for resistance.

Following Heidegger (2008), individuals always relate to their future possibilities. This means that, besides the ability to start anew, it is also inevitable that all living creatures will one day die. So the possibility of a second birth is, at the same time, a being-toward-death, expressed in Dasein, whereby the essential characteristic "resides in its understanding of itself as mortal" (Denizeau 2015:223). We experience the meaning of these parallel aspects of the human condition daily when events pass and are followed by others. But, in certain situations, this existential condition is particularly pronounced.

In this article, we have only touched on the results, but, still, our empirical illustrations show that the retirement process provides a practical sense and understanding of life as parallel beginnings and 
ends-second births and being-toward-death. A reason for this is that exiting employment is a situation that is imprinted with various degrees of uncertainty; we leave something behind as we move towards something new. Our suggestion is that the ambiguity of existence is even more prominent in the retirement process since it is a life event that breaks one's daily habits and because the event involves such a concrete experience of both an end and a new beginning and, therefore, may be an important existential imperative. From this perspective, we hope this article will not only be read as a proposal for a perspective and a methodology when studying the retirement process; for those interested in the existential dimensions of social life, retirement can also be seen as a critical (empirical) case, whereby particularly existential meaning aspects appear.

One essential aspect of the socio-biographical methodology is the analysis of social structures through individuals' narratives and existential meaning-making. In the research project, we have studied how women and men, with various experiences of occupational life and economic and social resources, exit Swedish working life through the mandatory institution of retirement and how they create existential meaning in their new life within the limits of structural conditions. In the analysis of the empirical data, we have linked how individuals shape and transform existential meaning against the background of social institutions, resource structures, and norms (cf. Bengtsson et. al 2017; Bengtsson and Flisbäck 2017). Here, the raised retirement age in Sweden, mentioned in the introduction, is interesting. As Jackson (2011) emphasizes, our attempts to create meaningful lives always happen within the limits of resources.

The Swedish pension reform is essentially part of the strong social norm and political principle of "the work strategy" in Swedish welfare politics, that is that one has an extensive responsibility to provide for oneself through gainful employment before one is eligible to receive social benefits. Even though this principle has long been decisive in the Swedish welfare model, it has been amplified in the new century (cf. Bengtsson 2014). From an existential sociology perspective, the increased responsibility for self-sufficiency higher up in the ages is interesting, as similar policies also set a limit for individuals' meaning-making (cf. Moulaert and Biggs 2013). The raised retirement age will likely be of great importance to those who regard their work as a calling, a life task that can hardly be completed in an easy way at some specific point in time, such as upon retirement. At the same time, we need to reflect upon what similar requirements to work longer might mean to those who cannot live up to social norms of being an active and productive individual in old age (cf. Ekerdt 1986; Katz 2000). How will these individuals, who cannot find a job due to issues such as sickness or ageism, create a life that they find meaningful, but that contrasts the norm that people should work longer? Additionally, how will similar resource-weak groups of the population find existential meaning in old age if they live under economic duress?

However, an important notion of our existential sociology perspective on retirement is that what a human being is, as well as what searching for meaning includes, cannot be predetermined (cf. Douglas 2010). Resource structures are only one aspect of the relationships out of which meaningful aspects of retirement emerge. Thus, it is important not to revert to a simplified picture in which capital accumulation results in greater life opportunities while capital loss results in difficulties. Losses-even of capital-can sometimes bring to light new meaning dimensions, resistance, and new directions in life. 


\section{References}

Alexander, Jeffrey C. and Philip Smith. 2003. “The Strong Program in Cultural Sociology: Elements of a Structural Hermeunetics." Pp. 11-26 in The Meanings of Social Life. A Cultural Sociology, edited by J. C. Alexander. Oxford: Oxford University Press.

Alwin, Duane F. 2012. "Integrating Varieties of Life Course Concepts." The Journals of Gerontology, Series B: Psychological Sciences and Social Sciences 67(2):206-220.

Arendt, Hannah. 1977. Eichmann in Jerusalem: A Report on the Banality of Evil. Harmondsworth: Penguin.

Arendt, Hannah. 1978. The Life of the Mind. New York: Harcourt.

Arendt, Hannah. 1997. Rahel Varnhagen: The Life of a Jewess. Baltimore, MD: Johns Hopkins University Press.

Arendt, Hannah. 1998. The Human Condition. Chicago: University of Chicago Press.

Atchley, Robert C. 1976. The Sociology of Retirement. Cambridge, MA: Schenkman.

Bengtsson, Mattias. 2014. "Towards Standby-Ability: Swedish and Danish Activation Policies in Flux." International Journal of Social Welfare 23(S1):54-70.

Bengtsson, Mattias and Marita Flisbäck. 2017. “On Leaving Work as a Calling: Retirement as an Existential Imperative." International Journal of Ageing and Later Life 11(1):37-67.

Bengtsson, Mattias and Marita Flisbäck. 2020. “Work as a Calling: Existential Dimensions of Individuals' Work Orientations." Pp. 75-101 in Work Orientations: Theoretical Perspectives and Empirical Findings, edited by B. Furåker and K. Håkansson. Abingdon, Oxfordshire: Routledge.

Bengtsson, Mattias, Marita Flisbäck, and Anna Lund. 2017. Farväl till arbetet: Sociologiska perspektiv på meningen med att gå i pension [Farewell to Labor. Sociological Perspectives on the Meaning of Retirement]. Lund: Nordic Academic Press.

Biggs, Simon. 2014. "The Promise of a Long Life? Cultural Adaptation to Productive Aging, Spiritual Empathy, and a Sustainable Future." Journal of Religion, Spirituality $\mathcal{E}$ Aging 26:96-108.
Biggs, Simon. 2015. "Theorising Ageing and the Question of a Long Life: Eye Openings." International Journal of Ageing and Later Life 10(1):9-20.

Braidotti, Rosi. 2011. Nomadic Subjects. Embodiment and Sexual Difference in Contemporary Feminist Theory. New York: Columbia University Press.

Collins, Randall. 2004. Interaction Ritual Chains. Princeton, NJ: Princeton University Press.

Dalby, Padmaprabha. 2006. "Is There a Process of Spiritual Change or Development Associated with Ageing? A Critical Review of Research." Aging \& Mental Health 10(1):4-12.

De Lange, Frits. 2011. "Inventing Yourself: How Older Adults Deal with the Pressure of Late-Modernity Identity Construction." Pp. 51-65 in Storying Later Life: Issues, Investigations, and Interventions in Narrative Gerontology, edited by G. Kenyon, E. Bohlmeijer, and W. L. Randall. Oxford: Oxford University Press.

Denizeau, Laurent. 2015. "Considering Human Existence: An Existential Reading of Michael Jackson and Albert Piette." Pp. 214-236 in What Is Existential Anthropology?, edited by M. Jackson and A. Piette. New York: Berghahn.

Douglas, Jack D. 2010. “Existential Sociology.” Pp. 3-73 in Existential Sociology, edited by J. D. Douglas and J. Johnson. Cambridge: Cambridge University Press.

Durkheim, Émile. 1995. The Elementary Forms of Religious Life. New York: Free Press.

Ekerdt, David J. 1986. “The Busy Ethic: Moral Continuity Between Work and Retirement." The Gerontologist 26(3):239-244.

Elder, Glen H. Jr., Monica Kirkpatrick Johnson, and Robert Crosnoe. 2003. "The Emergence and Development of Life Course Theory." Pp. 3-19 in Handbook of the Life Course, edited by J. T. Mortimer and M. J. Shanahan. New York: Kluwer Academic/Plenum.

Elias, Norbert. 1985. The Loneliness of Dying. Oxford: Blackwell.

Elias, Norbert and John L. Scotson. 1994. The Established and the Outsiders: A Sociological Enquiry into Community Problems. London: Sage. 
Erikson, Erik H. 1972. Young Man Luther: A Study in Psychoanalysis and History. London: Faber \& Faber.

Erikson, Erik H., Joan M. Erikson, and Helen Q. Kivnic. 1986. Vital Involvement in Old Age. New York, London: W.W. Norton \& Company.

Flisbäck, Marita. 2014a. När livet går bort, när livet kommer till. Existenssociologiska betraktelser av konstnärligt arbete, familjebildning och anhörigförlust [When Life Passes Away, When Life Arises: Contemplations of Artistic Work, Family Formation and Losses of Relatives from an Existential Sociology Perspective]. Lund: Studentlitteratur.

Flisbäck, Marita. 2014b. "Making Play or Playing the Game? On the Question of a 'Cleft Habitus' at the Doorway to the Art Field." Qualitative Sociology Review 10(4):52-67.

Fontana, Andrea. 1980. "Toward a Complex Universe: Existential Sociology." Pp. 155-181 in Introduction to the Sociologies of Everyday Life, edited by J. D. Douglas. Boston: Allyn and Bacon.

Frankl, Viktor E. 1988. The Will to Meaning: Foundations and Applications of Logotherapy. New York: Plume.

Giddens, Anthony. 1991. Modernity and Self-Identity: Self and Society in the Late Modern Age. Cambridge: Polity Press.

Halleröd, Björn, Johan Örestig, and Mikael Stattin. 2013. “Leaving the Labour Market: The Impact of Exit Routes from Employment to Retirement on Health and Wellbeing in Old Age." European Journal of Ageing 10(1):25-35.

Heidegger, Martin. 2008. Being and Time. New York: Harper Perennial.

Holm, Ulla. 2012. Att gå i pension är ingen barnlek [Retiring Isn't Child's Play]. Stockholm: Norstedts.

Hyde, Martin et al. 2004. "The Effects of Pre-Retirement Factors and Retirement Route on Circumstances in Retirement: Findings from the Whitehall II Study." Ageing and Society 24(2):279-296.

Jackson, Michael D. 2005. Existential Anthropology. Events, Exigencies and Effects. New York: Berghahn.

Jackson, Michael D. 2011. Life within Limits. Well-Being in a World of Want. Durham, London: Duke University Press.

Jackson, Michael D. 2013. Lifeworlds: Essays in Existential Anthropology. Chicago: University of Chicago Press.
Jackson, Michael D. 2015. "Existential Aporias and the Precariousness of Being." Pp. 155-177 in What is Existential Anthropology?, edited by M. Jackson and A. Piette. New York: Berghahn.

Jackson, Michael D. 2016. “Life and Concept.” Pp. 449-462 in Living and Dying in the Contemporary World. A Compendium, edited by V. Das and C. Han. Oakland: University of California Press.

Jackson, Michael D. and Albert Piette. 2015. "Anthropology and the Existential Turn." Pp. 1-29 in What is Existential Anthropology?, edited by M. Jackson and A. Piette. New York: Berghahn.

James, William. 1912. The Will to Believe: And Other Essays in Popular Philosophy. New York: Longmans, Green, and Co. The Project Gutenberg ebook.

Jonsson, Hans, Staffan Josephsson, and Gary Kielhofner. 2000. "Evolving Narratives in the Course of Retirement: A Longitudinal Study." The American Journal of Occupational Therapy 54(5):463-470.

Jonsson, Hans, Staffan Josephsson, and Gary Kielhofner. 2001. "Narratives and Experience in an Occupational Transition: A Longitudinal Study of the Retirement Process." The American Journal of Occupational Therapy 55(4):424-432.

Katz, Stephen. 2000. "Busy Bodies: Activity, Aging, and the Management of Everyday Life." Journal of Aging Studies 14(2):135-152.

Kaufmann, Walter. 1969. Existentialism from Dostoevsky to Sartre. Cleveland: Meridian Books.

Kimble, Melvin A. 2002. "Beyond the Biomedical Paradigm: Generating a Spiritual Vision of Ageing." Journal of Religious Gerontology 12(3-4):31-41.

Kotarba, Joseph A. and John M. Johnson. 2002. Postmodern Existential Sociology: A Sociology of Everyday Life. Walnut Creek, CA: AltaMira Press.

Luborsky, Mark R. 1994. “The Retirement Process: Making the Person and Cultural Meanings Malleable." Medical Anthropology Quarterly 8(4):411-429.

Manning, Peter K. 1973. "Existential Sociology." The Sociological Quarterly 14(2):200-225.

Marshall, Victor W. 1986. “Dominant and Emerging Paradigms in the Social Psychology of Aging." Pp. 9-33 in Later Life: The Social Psychology of Aging, edited by V. W. Marshall. Beverly Hills: Sage. 
Miller, Tina. 2015. “Going Back: 'Stalking', Talking and Researcher Responsibilities in Qualitative Longitudinal Research." International Journal of Social Research Methodology 18(3):293-305.

Moulaert, Thibauld and Simon Biggs. 2013. "International and European Policy on Work and Retirement: Reinventing Critical Perspectives on Active Ageing and Mature Subjectivity." Human Relations 66(1):23-43.

Muratore, Alexa M. and Joanne K. Earl. 2015. “Improving Retirement Outcomes: The Role of Resources, Pre-Retirement Planning and Transition Characteristics." Ageing \& Society 35(10):2100-2140.

Osborne, John W. 2012. "Existential and Psychological Aspects of the Transition to Retirement." European Journal of Psychotherapy and Counselling 14(4):349-363.

Reynolds, Frances, Alexandra Farrow, and Alison Blank. 2012. “'Otherwise It Would Be Nothing but Cruises': Exploring the Subjective Benefits of Working Beyond 65." International Journal of Ageing and Later Life 7(1):79-106.

Robertson, Ann. 2000. "II Saw the Handwriting on the Wall': Shades of Meaning in Reasons for Early Retirement." Journal of Aging Studies 14(1):63-79.

Thompson, Paul. 1993. "II Don't Feel Old': The Significance of the Search for Meaning in later Life." International Journal of Geriatric Psychiatry 8:685-692.
Thomson, Rachel and Julie McLeod. 2015. “New Frontiers in Qualitative Longitudinal Research: An Agenda for Research." International Journal of Social Research Methodology 18(3):243-250.

Tornstam, Lars. 2005. Gerotranscendence: A Developmental Theory of Positive Aging. New York: Springer.

Turner, Victor W. 1974. Dramas, Fields, and Metaphors. Symbolic Action in Human Society. Ithaca, London: Cornell University Press.

Van Gennep, Arnold. 1960. The Rites of Passage. Chicago: University of Chicago Press.

Van Solinge, Hanna and Kène Henkens. 2008. “Adjustment to and Satisfaction with Retirement: Two of a Kind?" Psychology and Aging 23(2):422-434.

Vasterling, Veronica. 2007. “Cognitive Theory and Phenomenology in Arendt's and Nussbaum's Work on Narrative." Human Studies Journal 35(1):79-95.

Wang, Mo and Kenneth S. Shultz. 2010. “Employee Retirement: A Review and Recommendations for Future Investigation." Journal of Management 36(1):172-206.

Weber, Max. 1994. "The Profession and Vocation of Politics." Pp. 309-369 in Political Writings, edited by P. Lassman and R. Speirs. Cambridge: Cambridge University Press.

\section{Citation}

Bengtsson, Mattias and Marita Flisbäck. 2021. "Illuminating Existential Meaning: A New Approach in the Study of Retirement." Qualitative Sociology Review 17(1):196-214. Retrieved Month, Year (http://www.qualitativesociologyreview.org/ENG/archive_eng.php). DOI: http://dx.doi.org/10.18778/1733-8077.17.1.12 